\title{
Rapid Production Methods for Ottawa-3 Rootstock and Branched Apple Nursery Stock
}

\author{
Eugene J. Hague ${ }^{1}$ and Denise Neilsen ${ }^{2}$ \\ Agriculture Canada Research Station, Summerland, B.C. VOH 1Z0 \\ Canada
}

Additional index words. tissue-culture, cuttings, Malus domestica

\begin{abstract}
A system for the rapid production of Ottawa-3 (0.3) rootstock (Malus domestica Borkh.) and branched apple nursery stock in the greenhouse is described. The time required for production of a finished' tree, $\approx 1$ year, compared favorably with traditional methods. Cuttings derived from tissue-cultured 0.3 rootstocks rooted well (up to $94 \%$ success rate), and the rooting effect persisted in cuttings from tissuecultured rootstocks grown for 1 year in the field. All combinations of two levels of $\mathrm{N}$ and $P$ in a Long Ashton nutrient solution were applied weekly to pots containing either tissue-cultured rootstocks or cuttings. The growth rate of tissue-cultured rootstocks exceeded that of cuttings. The growth rate of both sources of rootstocks increased in response to added $P$ and $N$. Growth of scion shoots ('Royal Gala') increased in response to $\mathbf{N}$. Branch production of 'Royal Gala' was greater for trees with the higher $\mathbf{P}$ and $\mathrm{N}$ rates. Trees on tissue-cultured rootstocks had more branches than those on cuttingderived roostocks at the higher level of $\mathrm{N}$.
\end{abstract}

In recent years there has been widespread acceptance of new apple cultivars in the marketplace and, concomitantly, interest in developing systems that can accommodate rapid changeover to new varieties. Dense plantings of trees on dwarfing rootstocks usually result in early and high fruit production. However, the supply of dwarfing rootstocks in North America has been inadequate, and this, combined with the slow production of finished trees, suggested the need for development of more rapid methods of producing rootstocks and finished trees.

Ottawa-3 (0.3) rootstock is a hardy, dwarfing rootstock that has been successfully used in Canada but that has the drawback of being difficult to propagate from softwood cuttings (Granger and Hogue, 1974) and stool beds (Quamme and Brownlee, 1990a). However, it has been reported to be readily propagated by tissue culture and from cuttings of plants derived from tissue culture (Quamme and Brownlee, 1990b). Webster and Jones (1989) reported similar findings of increased rooting ability for cuttings taken from stock plants derived from tissue-cultured M.9, which they attributed to rejuvenation, although no other morphological evidence of rejuvenation was presented. They noted also that high rates of rooting of cuttings persisted after several seasons in the field, provided that stock plants were severely pruned.

Stimulation of rapid early growth in for-

Received for publication 27 Feb. 1991. Contribution no. 776 of Agriculture Canada, Research Station, Summerland, B.C. The cost of publishing this paper was defrayed in part by the payment of page charges. Under postal regulations, this paper therefore must be hereby marked advertisement solely to indicate this fact.

Research Scientist.

${ }^{2}$ Visiting Fellow. estry nursing stock of Scotch pine (Pinus silvestris L.) and Norway spruce [Picea abies (L.) Karst.] grown in the greenhouse in nutrient solution has been reported by Ingestadt (1979). High growth rates were achieved by increasing the frequency and amount of nutrient additions to match plant nutrient demands, thus maintaining a predetermined optimum balance of nutrients within the plant.

The present study was undertaken to devise methods for rapidly producing 0.3 rootstocks using tissue culture and cuttings under greenhouse conditions; to compare the relative efficiencies of these methods in the production of branched nursery stock; and to compare the effects of varied, frequent, small additions of $\mathrm{N}$ and $\mathrm{P}$ on growth rates and tree development.

Producing branched trees on tissue-cultured rootstocks. Between 1988 and 1989 four lots of tissue-cultured 0.3 rootstock (each lot contained from 29 to 88 plants, 188 plants total) were obtained from AgriForest Indus-

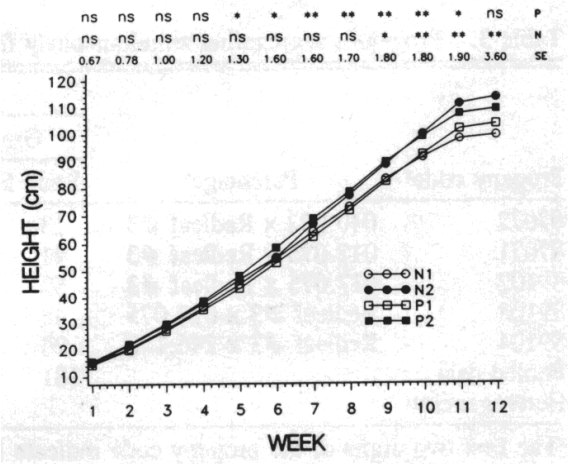

Fig. 1. Growth of Ottawa-3 rootstock transplanted in soil : perlite : peat mix over time in response to $\mathrm{N}$ and $\mathrm{P}$ fertilization. $\mathrm{N}_{1}, \mathrm{P}_{1}$ and $\mathrm{N}_{2}, \mathrm{P}_{2}$ : Long Ashton nutrient solution $\times 1$ and $\times 2$, respectively. 
Table 1. Time required for each stage in the production of apple trees from micropropagated Ottawa3 explants and cuttings.

\begin{tabular}{|c|c|c|c|c|c|}
\hline \multirow[b]{4}{*}{ Stage } & \multicolumn{5}{|c|}{ Time (weeks) } \\
\hline & \multicolumn{4}{|c|}{ Micropropagated rootstocks } & \multirow{3}{*}{$\begin{array}{c}\frac{\text { Cuttings }}{5} \\
(\mathrm{n}=32)\end{array}$} \\
\hline & \multicolumn{4}{|c|}{ Lot } & \\
\hline & $\begin{array}{c}1 \\
(n=88)\end{array}$ & $(\mathrm{n}=39)$ & $\begin{array}{c}3 \\
(n=29)\end{array}$ & $\begin{array}{c}4 \\
(n=32)^{z}\end{array}$ & \\
\hline \multicolumn{6}{|l|}{ Rootstock growth } \\
\hline Explants in mist & & 4 & $1-3$ & $2-5$ & $6^{y}$ \\
\hline Plantlets in nutr. solution & 9 & 22 & $7-9$ & $5-8$ & $12^{x}$ \\
\hline Transplants in soil mix & 14 & & $8-10$ & 11 & 12 \\
\hline To buddable rootstock & 23 & 26 & $16-22$ & $18-24$ & 30 \\
\hline \multicolumn{6}{|l|}{ Scion growth } \\
\hline $\begin{array}{l}\text { Chip-budding to bud growth } \\
\text { Shoot growth }\end{array}$ & $\cdots$ & & -- & 1.5 & 1.5 \\
\hline $\begin{array}{l}\text { Shoot growth } \\
\text { Branching }\end{array}$ & $\cdots$ & 26 & 10 & 5 & 5 \\
\hline $\begin{array}{l}\text { Branching } \\
\text { Cold storage }\end{array}$ & $\cdots$ & & 14 & 12 & 12 \\
\hline $\begin{array}{l}\text { Cold storage } \\
\text { Total }\end{array}$ & & $8-10$ & $8-10$ & 10 & 10 \\
\hline & & $60-62$ & $48-56$ & $46.5-52.5$ & 58.5 \\
\hline
\end{tabular}

${ }^{\text {Mean }}$ of all nutrition treatments.

yFrom micropropagated rootstock.

${ }^{\times}$Rooting in perlite in mist room.

Table 2. Rooting of Ottawa-3 nonlignified wood cuttings taken from tissue-cultured plants and several sources after 6 weeks in perlite in a mist room.

\begin{tabular}{|c|c|c|c|c|c|c|}
\hline \multirow[b]{2}{*}{ Source } & \multirow[b]{2}{*}{$\begin{array}{l}\text { Region of } \\
\text { shoot used }\end{array}$} & \multicolumn{5}{|c|}{ Cuttings } \\
\hline & & $\begin{array}{l}\text { Total } \\
\text { (no.) }\end{array}$ & $\begin{array}{c}\text { Not } \\
\text { callused }\end{array}$ & Callused & Rooted & Decayed \\
\hline \multirow{3}{*}{ Field nursery } & & & \multicolumn{4}{|c|}{$\%$} \\
\hline & Top $1 / 3$ & 21 & 0 & 10 & 91 & 0 \\
\hline & Lower 2/3 & 39 & 0 & 44 & 54 & 3 \\
\hline \multirow{3}{*}{ Greenhouse B } & Mixed & 33 & 0 & 6 & 94 & 0 \\
\hline & Top $1 / 3$ & 30 & 0 & 13 & 77 & 10 \\
\hline & Lower $2 / 3$ & 62 & 9.7 & 32 & 58 & 0 \\
\hline
\end{tabular}

Table 3. Effect of propagation method and $\mathrm{N}$ on diameter of Ottawa-3 rootstocks.

\begin{tabular}{lcr}
\hline \hline $\begin{array}{l}\text { Propagation } \\
\text { method }\end{array}$ & $\begin{array}{c}\mathrm{N} \\
\text { level }\end{array}$ & $\begin{array}{c}\text { Diameter } \\
(\mathrm{mm})\end{array}$ \\
\hline Cuttings & $\mathrm{N}_{1}$ & 8.17 \\
& $\mathrm{~N}_{2}$ & 8.51 \\
Tissue culture & $\mathrm{N}_{1}$ & 9.25 \\
& $\mathrm{~N}_{2}$ & 10.31 \\
SE $(\mathrm{A})^{\mathrm{y}}$ & & 0.41 \\
$\mathrm{SE}(\mathrm{B})^{\mathbf{x}}$ & & 0.35 \\
\hline
\end{tabular}

${ }^{\mathrm{z}} \mathrm{N}_{1}$ and $\mathrm{N}_{2}$ : Long Ashton nutrient solution with $\times 1 \mathrm{~N}$ and $\times 2 \mathrm{~N}$, respectively.

${ }^{y_{S E}}(A)$ is SE difference between two propagation methods at one or different levels of $\mathrm{N}$.

${ }^{x_{S E}(B)}$ is SE difference between two levels of $N$ within one propagation method.

tries, Kelowna, B.C. The cultures were derived from a single plant but not a single bud and were renewed every 2 years. When obtained, the explants were in an agar rooting medium, $\approx 30$ per $450-\mathrm{ml}$ jar, and most had several roots 10 to $30 \mathrm{~mm}$ in length. The explants were removed from the sterile agar medium and each was inserted through the perforated cover of a 300-ml carton cup filled with a Long Ashton complete nutrient solution (LAS) (Hewitt, 1966), allowing only the roots to be submerged. The plants were placed in a mist room in a greenhouse with a misting interval of $3 \mathrm{~min} / 10 \mathrm{~min}$, no supplemental light, no bottom heat, and with air at 20/16C (day/night). Plantlets were left in the mist room until roots began to elongate, usually after 4 to 6 days, but for some as long as 21 days. The plantlets were then rootstocks 7 to 10 days after scion budding, as described in the process above, or from tissue-cultured rootstocks after one season's growth in the nursery and were soft, nonlignified wood (Macdonald, 1986). The top 10 to $15 \mathrm{~cm}$ of each of these shoots was discarded because it was still actively growing and prone to decay in the propagation chamber. The shoots were cut into $12-$ to $18-\mathrm{cm}$ sections, all leaves except the top two removed, and the bases dipped for $10 \mathrm{sec}$ into 2000 ppm indolebutyric acid in a 50\% ethanol solution. The cuttings were placed into perlite in a greenhouse room with intermittent mist for 4 to 8 weeks and then checked for amount of rooting and decay.

Response of tissue-culture explants and cuttings to $N$ and $P$ regimes. Thirty-two tissue culture 0.3 explants (lot 4 ) were grown as described above until potted in a 1 peat : 1 perlite : 1 silt loam soil mix (by volume). Ottawa-3 cuttings were taken from tissuecultured budded rootstocks, rooted as described above for shoot cuttings, and 32 (lot 5) were plantedl directly into soil mix in 0.5 liter plastic pots and stored in a room at $3 \mathrm{C}$ for 10 weeks. Lots 4 and 5 were then transferred into a cool greenhouse (10 to 12C) for 1 week, and then to a warm greenhouse for 2 weeks (18C night, 24C day). The cuttings were then planted into 9-liter pots in soil mix. Four did not survive. Cuttings (seven replicates) and explants (eight replicates) were grown separately with weekly applications of $200 \mathrm{ml}$ LAS or modified LAS to give all combinations of two levels of $\mathrm{N}$ (LAS; LAS with $2 \times \mathrm{N}$ ) and two levels of P (LAS; LAS with $2 \times \mathrm{P}$ ) in a randomized complete-block design. Cuttings and explants were then grown for either 11 weeks (explants) or 12 weeks (cuttings) before being budded with 'Royal Gala'. Nutrition treatments were stopped when rootstock shoots were removed ( 7 days after budding) and were resumed 1.5 to 2 weeks after scion budbreak. Branching was induced by a combination of tipping and removal of the top four leaves when plants were 60 to $70 \mathrm{~cm}$ and again when 80 to $90 \mathrm{~cm}$ high.

Diameter of cuttings, at planting, and of all plants before budding was measured at 5 $\mathrm{cm}$ above the soil. Initial diameter of explants was measured just above the basal rosette of leaves. Height was measured every week. After branch induction, branches were counted weekly. Data for explants and cuttings were combined for analysis into a modified split-plot experiment with propagation method assigned to main plot units and $\mathrm{N}$ and $\mathrm{P}$ treatments to subplot units. The error for testing propagation-type effects was determined as blocks in propagation type rather than as block $\times$ propagation interaction because cuttings and explants were grown separately. Otherwise, analysis of variance was as outlined by Steele and Torrie (1960).

Timetable for the production of branched trees from tissue-culture explants and cuttings. The time required to produce a buddable rootstock (Table 1) varied from 16 to 26 weeks for tissue-culture explants (lots 14) and was 30 weeks for cuttings (lot 5). As indicated for lots 3 and 4, explants did not 

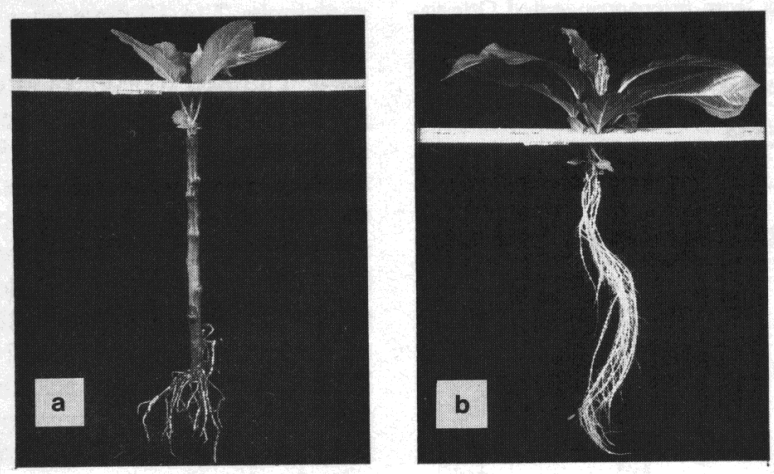

Fig. 2. Rooting of Ottawa-3 rootstock from two propagation methods before planting in soil mix: (a) cutting; (b) tissue-culture.

Table 4. Effect of rootstock propagation method, N, and P on branching of 'Royal Gala' on Ottawa3 rootstock.

\begin{tabular}{lcccc}
\hline \hline & & \multicolumn{2}{c}{ Branches (no.) } \\
\cline { 3 - 4 } Treatment & Levels $^{z}$ & $>5 \mathrm{~cm}$ & $<5 \mathrm{~cm}$ & Total \\
\hline Phosphorus & $\mathrm{P}_{1}$ & 2.3 & 1.9 & 4.2 \\
Propagation & $\mathrm{P}_{2}$ & 2.8 & 2.7 & 5.5 \\
Cuttings & & & 1.1 & 2.8 \\
& $\mathrm{~N}_{1}$ & 1.7 & 2.3 & 4.9 \\
Tissue culture & $\mathrm{N}_{2}$ & 2.5 & 1.7 & 3.5 \\
& $\mathrm{~N}_{1}$ & 1.8 & 4.2 & 8.2 \\
SE(A) & $\mathrm{N}_{2}$ & 4.0 & 0.34 & 0.38 \\
SE(B) & & 0.25 & 0.59 & 0.69 \\
SE(C) & & 0.40 & 0.49 & 0.53 \\
\hline
\end{tabular}

${ }^{2} P_{1}, N_{1}$, and $P_{2}, N_{2}$ : Long Ashton nutrient solution with $P, N \times 1$ and $P, N \times 2$, respectively. $y_{S E}(A)$ is SE for the difference between two levels of $P$.

${ }^{x_{S E}}(\mathrm{~B})$ is SE for the difference between two propagation methods at one or different levels of $\mathrm{N}$.

${ }^{w_{S E}}(\mathrm{C})$ is SE for the difference between two levels of $\mathrm{N}$ within one propagation method.

all grow at the same rate, although by the end of the rootstock growth period, earlier differences had usually disappeared. Budding, scion growth, and branching of scion took from 19 to 26 weeks for tissue-cultured rootstocks and 19 weeks for cuttings. The timetable outlined compared favorably with traditional methods of apple nursery stock production. For example, shoots from established stool beds are normally harvested once annually (Quamme and Brownlee, 1990a) and then grown for another season before being grafted or budded, followed by another 1 or 2 years of scion growth. Moreover, the efficiency of. the production system outlined here was increased by the use of cuttings from tissue-cultured rootstocks 9 to 10 days after scion budding. Thus, because of the relatively short time span required, this procedure is more flexible and sensitive to needs for new scion/rootstock combinations for both grower and researcher than are traditional production methods.

The proposed time-table could be modified at any point after rootstock growth so that plants could be diverted to field nurseries or cold storage. Scion growth could also be prolonged, depending 'on the trunk diameter and branching required.

Rooting of cuttings. Cuttings from micropropagated 0.3 rootstocks rooted well $(\mathrm{Ta}-$ ble 2). Losses of cuttings from decay ranged from $0 \%$ to $10 \%$ and noncallusing of cuttings from $0 \%$ to $9 \%$. Difficulties in rooting 0.3 rootstock have been previously reported
(Granger and Hogue, 1974), and Quamme and Brownlee (1990a) reported that only $20.5 \%$ of shoots of 0.3 rooted in stool beds. Quamme and Brownlee (1990b) have reported improved rooting of $\mathrm{O} .3$ cuttings from micropropagated sources. This improvement may possibly be attributable to rejuvenation of the clone $(\mathrm{H}$. Quamme, personal communication), as has been suggested for M.9 rootstock by Webster and Jones (1989).

There appeared to be no loss of rooting ability in micropropagated stock after one season's growth in the field (Table 2), which corroborated the findings of Webster and Jones (1989) that characteristics imparted during apparent rejuvenation in tissue culture persisted in field-grown micropropagated plants. Rooting ability was higher for cuttings from the top one-third of the shoot than from the bottom two-thirds (where this distinction was made).

Effects of propagation method, $N$, and $P$ on the production of branched trees. Rootstocks from tissue-culture explants grew faster than those from cuttings, even though cuttings were initially taller than explants, as indicated by significantly different heights during the first 2 weeks of the experiment (data not shown), so that by the 11 th week explants had overtaken the cuttings and were significantly taller than cuttings $(P<0.05)$. Thus, the apparent decline in growth rate at week 12 occurred because that point included data for cuttings alone. Phosphorus caused an increase in rootstock height be- tween 5 and 11 weeks of growth, and $\mathrm{N}$ caused an increase after 9 weeks of growth (Fig. 1).

There was a significant interaction effect between propagation method and $\mathrm{N}$ on rootstock diameter measured before budding (Table 3). Tissue-cultured rootstocks had a larger diameter than rootstocks from cuttings at each level of N. Nitrogen increased the diameter of tissue-cultured plants but not of cuttings. Initial average diameter of tissuecultured rootstocks was $3.9 \mathrm{~mm}$; thus, on average, diameter increased over the 11 weeks of growth at the rate of $0.53 \mathrm{~mm}$-week-'. Initial average diameter for cuttings was 5.35 $\mathrm{mm}$; thus, on average, diameter increased at the rate of 0.32 mm-week- .

Bud take was $100 \%$ for cutting-derived rootstocks and 97\% (one unsuccessful bud) for tissue culture-derived rootstocks. Scion growth was more rapid than rootstock growth over the 5 weeks before branch induction (data not shown) and increased in response to N. There were no effects of either propagation method or $\mathrm{P}$ on scion height.

There was a significant effect of $\mathrm{P}$ and a significant interaction effect between propagation method and $\mathrm{N}$ on the production of branches after 14 weeks of scion growth (Table 4). Phosphorus increased the number of branches for both propagation methods. Nitrogen also increased the number of branches for both propagation methods, but the effect was greater for tissue-cultured plants than for cuttings at the higher level of $\mathrm{N}$.

The higher growth rate of tissue-cultured rootstocks, as measured by height and diameter, may have resulted from a larger root volume at planting time (Fig. 2). Although tissue-cultured plants had roots that had developed in nutrient solution, their immediate growth response when transplanted to soil (Fig. 1) suggested that their root systems were at least as functional as those of cuttings that had been developed in soil mix. Early top growth response to $\mathrm{P}$ also may be attributable to $\mathrm{P}$ effects on early root system development (Drew and Saker, 1978), as the effect of $\mathrm{P}$ on height had diminished by the end of the rootstock phase and was not evident during scion growth.

Changes in rootstock and scion height were about linear over time, although there was a decline in growth rate of trees in the low $\mathrm{N}$ treatment after the 9th week (Fig. 1), which indicated that $\mathrm{N}$ additions were ceasing to meet demand. Plots of height against fresh weight for apple seedlings have indicated that, as height increased linearly, fresh weight increased exponentially (J. Beulah, personal communication); thus, rootstocks and scions were in an exponential growth phase. Ingestadt (1979) maintained a constant relative growth rate (fresh-weight basis) during the exponential growth phase of pine and spruce seedlings by matching frequency and cornposition of nutrient additions to a predetermined plant nutrient demand. Consequently, there is probably potential for increasing the growth rate of rootstocks and scions by changing the balance of nutrients within the fertilizer solution and by increasing the fre- 
quency of fertilizer additions, although this will have to be determined in future studies.

Branched nursery stock has been shown to give rise to earlier fruit production (van Oosten, 1978). In the present study, increases in branch production in response to $\mathrm{N}$ may have been a function of the higher growth rate that occurred in rootstock and scion at the higher level of $\mathrm{N}$, as vigor has been cited as a factor in promoting branching (Larsen, 1979). Growth responses to $\mathrm{P}$ and propagation method were only apparent during rootstock growth so that it is more difficult to explain their effects on scion branching by increases in vigor alone. However, production of cytokinins has been linked to $\mathrm{P}$ nutrition for sycamore (Platanus occidentalis L.) (Dhillon, 1978), and the interaction of endogenous cytokinins and auxins has been considered to play an important role in controlling lateral bud activity (Sachs and Thimann, 1967). At present, no explanation can be offered for the effect of propagation method on branching.

We have developed a rapid method of growing apple rootstocks from tissue-culture explants, budding these to new cultivars, and growing them to the stage of a branched tree in $\approx 1$ year. This interval compared very favorably with traditional methods of producing finished trees by planting rooted liners from a stool bed, budding these in the year of planting, and growing the scion a mini- mum of another year in the nursery. The method also incorporated the production of plants. from cut rootstock shoots, thus increasing its efficiency. The cuttings from these shoots rooted well and this was attributed to a possible rejuvenation of the 0.3 rootstock during tissue culture. This effect persisted in cuttings from plants grown for 1 year in the field.

Rapidity of growth and degree of branching were shown to vary directly with $\mathrm{N}$ and $\mathrm{P}$ nutrition and were greater for trees from tissue-culture explants than from cuttings. Manipulation of $\mathrm{N}$ and $\mathrm{P}$ nutrition in terms of rates and frequency of application to increase growth rate warrants further study.

\section{Literature Cited}

Dhillon, S.J. 1978. Influence of varied P supply on growth and xylem sap cytokinin level of sycamore (Platanus occidentalis L.) seedlings. Plant Physiol. 61:521-524.

Drew, M.C. and L.R. Saker. 1978. Nutrient supply and the growth of the seminal root system in barley. III. Compensatory increase in growth of lateral roots, and in rates of phosphorus uptake, in response to a localized supply of phosphate. J. Expt. Bot. 29:435-451.

Granger, R.L. and E.J. Hogue. 1974. Propagating apple rootstocks by root cuttings. Agr. Can. Tech. Bul. J550.

Hewitt, E.J. 1966. Sand and water culture methods used in the study of plant nutrition. Tech. Commun. 22. Cmwlth. Bur. Hort. Plantation
Crops. E. Malling, U.K.

Ingestadt, T. 1979. Mineral nutrient requirements of Pinus silvestris and Picea abies seedlings. Physiol. Plant 45:373-380.

Larsen, F.E. 1979. Chemical stimulation of branching in deciduous tree fruit nursery stock with ethyl 5-(4-chlorophenyl)- 2H-tetrazole-2acetate. J. Amer. Soc. Hort.. Sci. 104(6):770773.

Maedonald, B. 1986. Practical woody plant prop agation for nursery growers. vol. 1. Timber Press, Portland, Ore.

Popenoe, J. and B.H. Barritt. 1988. Branch induction by growth regulators and leaf removal in 'Delicious' apple nursery stock. HortScience 23:859-862.

Quamme, H.A. and R.T. Brownlee. 1990a. Stool layering ability of thirty-one apple rootstock cultivars. Fruit Var. J. 44:165-169.

Quamme, H.A. and R.T. Brownlee. 1990b. Rootstocks for high density apple plantings in British Columbia. Agr. Can. Summerland B.C. Tech. Rpt. 90-02.

Sachs, T. and K.V. Thimann. 1967. The role of auxins and cytokinins in the release of buds from dominance. Nature (London) 201:939-940.

Steele, R.G.D. and J.H. Torrie. 1960. Principles and procedures of statistics. McGraw-Hill, New York.

van Oosten, H.J. 1978. Effects of initial tree quality on yield. Acta Hort. 65:123-127.

Webster, C.A. and O.P. Jones. 1989. Effects of sustained subculture on apparent rejuvenation of the apple rootstock M.9 in vitro and in vivo. Ann. Sci. For. 46 suppl:187S-189s. 